\title{
Localization of Cannabinoid Receptor 1 (CB1) in Submandibular and Sublingual Salivary Glands of Mice throughout Postnatal Development
}

\author{
Localización de los Receptores Cannabinoides 1 (CB1) en Glándulas Salivales \\ Submandibulares y Sublinguales de Ratones Durante el Desarrollo Postnatal
}

\author{
Wiphawi Hipkaeo*; Masahiko Watanabe** \& Hisatake Kondo,****
}

\begin{abstract}
HIPKAEO, W.; WATANABE, M. \& KONDO, H. Localization of cannabinoid receptor 1 (CB1) in submandibular and sublingual salivary glands of mice throughout postnatal development. Int. J. Morphol., 33(2):695-700, 2015.

SUMMARY: In view of the fact that human marijuana users often show dry mouth symptom, the present study was attempted to examine the localization of CB1, which was originally identified in brain, in the submandibular and sublingual salivary glands of postnatal developing male mice by immunohistochemistry. In submandibular gland, CB1-immunoreactivity was positive in a majority of acinar cells in forms of granular appearance in their apical cytoplasm, while it was negative in the ducts at newborn stage. The immunoreactivity decreased in the acinar cells at P1W and no immunoreactivity was detected in the acinar cells at P3W and thereafter. The immunoreactivity was positive in ductal cells at P3W and it remained positive thereafter until P8W stage. The immunoreaction was distinct on the apical plasmalemma of the intercalated ductal cells, while it was distinct on the basal plasmalemma of the granular convoluted ductal cells. The enhanced immunostaining on the lateral plasmalemma of the granular ductal cells was discerned only on P6W. In sublingual gland, CB1-immunoreactivity was detected in the demilune acinar cells and ductal cells only on P4W. Furthermore, CB1-immunoreactivity was shown to occur in the salivary ganglionic neurons, suggesting the CB1-inhibitory action in the saliva secretion through the parasympathetic nervous transmission.
\end{abstract}

KEY WORDS: Cannabinoid receptor 1; Immunohistochemistry; Submandibular gland; Sublingual gland; Postnatal mice.

\section{INTRODUCTION}

Cannabinoids, natural components derived from the plant Cannabis sativa, have been known for many years as pharmacological properties, psychotropic drugs and medicinal agents with diverse systemic effects. The actions of cannabinoids in mammalian tissues have been clarified to be primarily mediated by two main types of cannabinoid receptor: $\mathrm{CB} 1$ and $\mathrm{CB} 2$ receptors whose cDNA cloning was already succeeded (Matsuda et al., 1990; Matsuda, 1997; Kano et al., 2009). The CBs belong to the $\mathrm{G}$ protein-coupled receptor superfamily. $\mathrm{N}$-arachidonoylethanolamide (anandamide) and 2-arachidonoy- lglycerol (2-AG) have also been identified as endogeneous ligands, commonly termed endocannabinoids (eCB), for these receptors (Busch et al., 2004). CB1 receptors are expressed at high levels in the central and peripheral nervous systems, where their main role is to retrogradely modulate neurotransmitter release
(Freund et al., 2003; Osborne et al., 2009; Navarrete \& Araque, 2010). CB2 receptors are found in immune cells as well as within the cardiovascular gastrointestinal systems (Pertwee, 2001; Sanger, 2007; Wright et al., 2008).

The activation of $\mathrm{CB}$ receptors have been demonstrated to inhibit agonist-stimulated salivation and modify saliva contents, in accord with the known fact that marijuana users often decreases saliva secretions (Kopach et al., 2011). There have been several studies demonstrating that $\mathrm{CB} 1$ receptor is localized mainly in the ductal system, whereas $\mathrm{CB} 2$ receptor is in the acini in immunohistochemistry (Busch et al.; Prestifilippo et al., 2006; Dall'Aglio et al., 2010). Considering the fact that the development and differentiation of the duct-acinus system of the salivary gland progress at early postnatal stages of

\footnotetext{
* Department of Anatomy, Faculty of Medicine, Khon Kaen University, Khon Kaen, Thailand.

** Department of Anatomy, Graduate School of Medicine, Hokkaido University, Sapporo, Japan.

**** Histology Laboratory, Keiai-kai Medical Corporation, Maesawa, Japan.
} 
mice (Zajicek et al., 1985; Denny et al., 1990), and also that the salivary glands are under controlled by their specific parasympathetic nervous system, it is meaningful to examine the localization of $\mathrm{CB} 1$ in the parasympathetic ganglion as well as in the glands during the course of postnatal development of mice by immunohistochemistry, which was the main purpose of the present study.

\section{MATERIAL AND METHOD}

Male albino mice of postnatal 1day (P1D), 1 week (P1W), P3W, P4W, P6W, P8W were perfused with $10 \mathrm{ml}$ PBS, followed by $10 \mathrm{ml} 4 \%$ paraformaldehyde $/ 0.1 \mathrm{M}$ phosphate buffer. The submandibular and sublingual glands were removed, then postfixed with the same fixative for 2 h. Specimens were dipped into $30 \%$ sucrose $/ 0.1 \mathrm{M}$ phosphate buffer for cryoprotection. Cryosections of $20 \mathrm{~mm}$ thickness were made and permeabilized with $0.1 \%$ TritonX-100/PBS for $20 \mathrm{~min}$ at room temperature, incubated with $0.3 \% \mathrm{H} 2 \mathrm{O} 2 /$ methanol for $10 \mathrm{~min}$, then $5 \%$ normal goat serum/PBS for $30 \mathrm{~min}$. Sections were incubated with mouse CB1 rabbit $\mathrm{IgG}(1 \mathrm{mg} / \mathrm{ml})$ overnight at room temperature. The specificity of the antibodies was confirmed previously using CB1 gene knockout mice (Uchigashima et al., 2007). The sections were subsequently incubated for $1 \mathrm{~h}$ at room temperature with biotinylated anti-rabbit IgG secondary antibody (Vector Laboratories, Burlingame, CA USA) diluted at 1:250 for DAB reaction by VECTASTAIN Elite ABC kit (Vector Laboratories, Burlingame, CA USA). In control experiments, omission of the primary antibody was applied to sections. All procedures were conducted in accordance with Guidelines for the Care and Use of Laboratory Animals at Khon Kaen University. This study was approved by the Animal Ethics Committee of the Khon Kaen University, based on the Ethics of Animal Experimentation of the National Research Council of Thailand (Reference No.AEKKU 4/2014).

\section{RESULTS}

Submandibular gland. On postnatal 1 day (P1D), weak immunoreactivity for $\mathrm{CB} 1$ was detected in some acinar cells and the immunopositive materials were localized in the apical cytoplasm in forms of fine granules in the submandibular gland. No significant immunoreactivity was detected in the proximal or distal ductal cells throughout the gland (Fig. 1).

On postnatal 1 week (P1W), the weak and granular immunoreactivity in the acinar cells remained although the

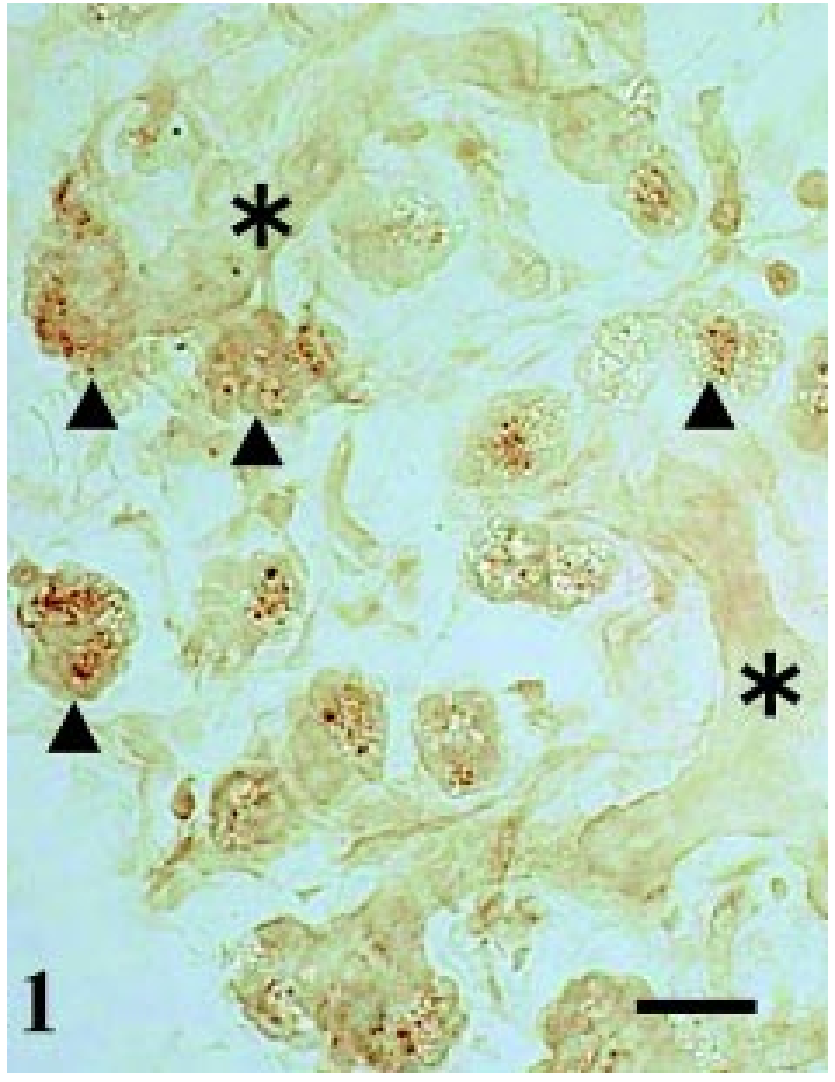

Fig. 1. Acini of submandibular gland on postnatal 1 day of mice. Immunoreactive materials in forms of fine granules are recognized in some acinar cells (arrowheads). No immunoreactivity is seen in ductal cells (asterisks). Bar represents $20 \mu \mathrm{m}$.

number of the immunopositive cells decreased. No immunoreactivity was seen in the ductal cells throughout the submandibular gland (data not shown).

On P3W, no immunoreactivity was detected in the acinar cells or ductal cells from the proximal to distal ducts (Fig. 2).

On P4W, while no immunoreactivity was maintained in the acinar cells, distinct immunoreactivity was seen in ductal cells throughout the intercalated, granular and striated portions of the distal ducts as well as the proximal excretory ducts (Fig. 3). In the intercalated portions, the immunoreactivity was distinct along the apical plasmalemma, although the entire cytoplasm was diffusely immunostained (Fig. 3a and 3b). In the granular portions, the immunoreactivity was confined to the basal cytoplasm with the basal plasmalemma distinct, while the lateral plasmalemma was much less distinct (Fig. 4).

On P6W, although the immunoreactivity pattern in the ductal cells was generally similar to the previous stage, 


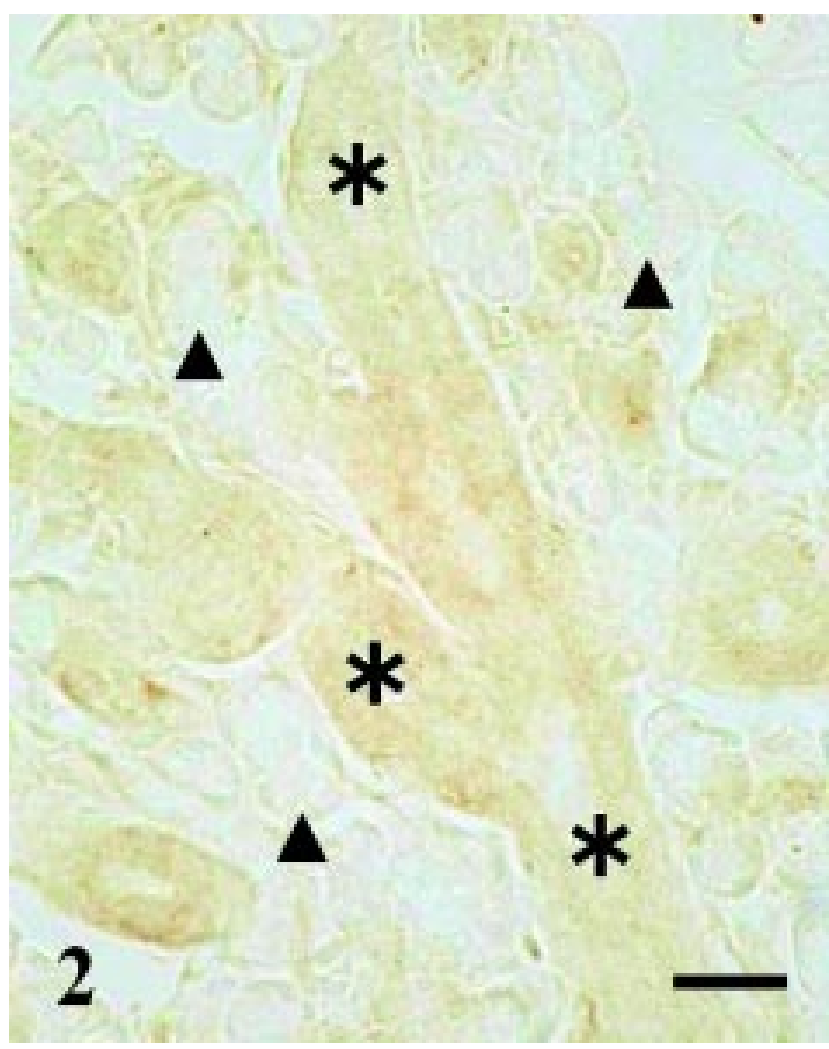

Fig. 2. Submandibular gland on $\mathrm{P} 3 \mathrm{~W}$ of mice. No significant immunoreactivity was discerned in acinar cells (arrowheads) or ductal cells (asterisks). Bar represents $20 \mu \mathrm{m}$.

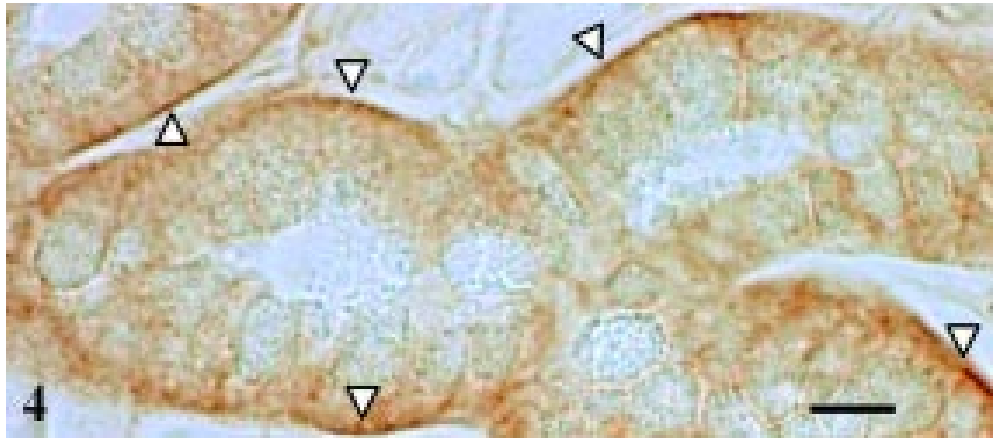

Fig. 4. Higher magnification immuno-light micrograph of granular convoluted ducts shown in Fig. 3. Note distinct deposits of immunoreaction along the basal plasmalemma (blank arrowheads), but no immunoreaction along the apical plasmalemma as well as the apical cytoplasm occupied with secretory granules. Bar represents $20 \mu \mathrm{m}$.

the immunoreaction was distinct in the lateral as well as basal plasmalemma of the granular convoluted portions of distal excretory ducts, resulting in clear appearance of immunostained honeycomb patterns for the contours of individual ductal cells when the ducts were cut obliquely (Fig. 5)

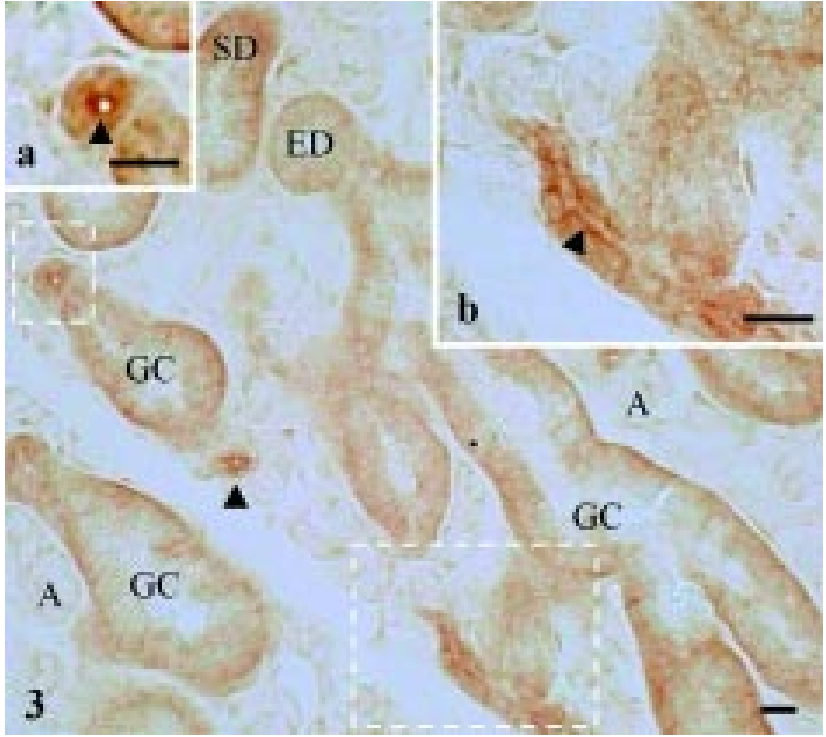

Fig. 3. Granular convoluted ducts (GC) of submandibular gland on $\mathrm{P} 4 \mathrm{~W}$ of mice. Immunoreactive material was distributed diffusely in the cytoplasm with distinct deposits along the basal plasmalemma. Note distinct immunoreaction along the apical plasmalemma (arrowheads) of intercalated ducts enclosed by rectangles, whose higher magnification images are shown in (a) and (b). $A=$ acinar cell; $\mathrm{ED}=$ excretory duct; $\mathrm{SD}=$ striated duct. Bar represents $20 \mu \mathrm{m}$.

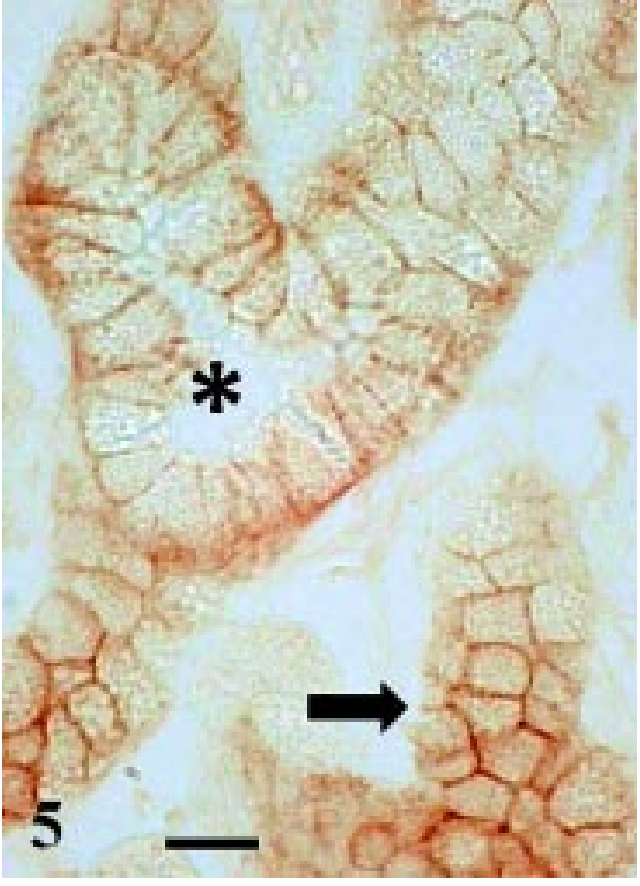

Fig. 5. Granular convoluted ducts (*) of submandibular gland on P6W. Note distinct immunoreactivity along the lateral plasmalemma of individual ductal cells without significant immunostaining along the apical plasmalemma. Also note polyhedral networks (thick arrow) of immunostained lateral plasmalemma in tangentially cut granular ducts. Bar represents $20 \mu \mathrm{m}$. 
On P8W, the immunoreactivity decreased in the ductal cells and it appeared diffuse with the basal cytoplasm slightly more distinct. However, the lateral plasmalemma was not distinct different from the previous stage (Fig. 6).

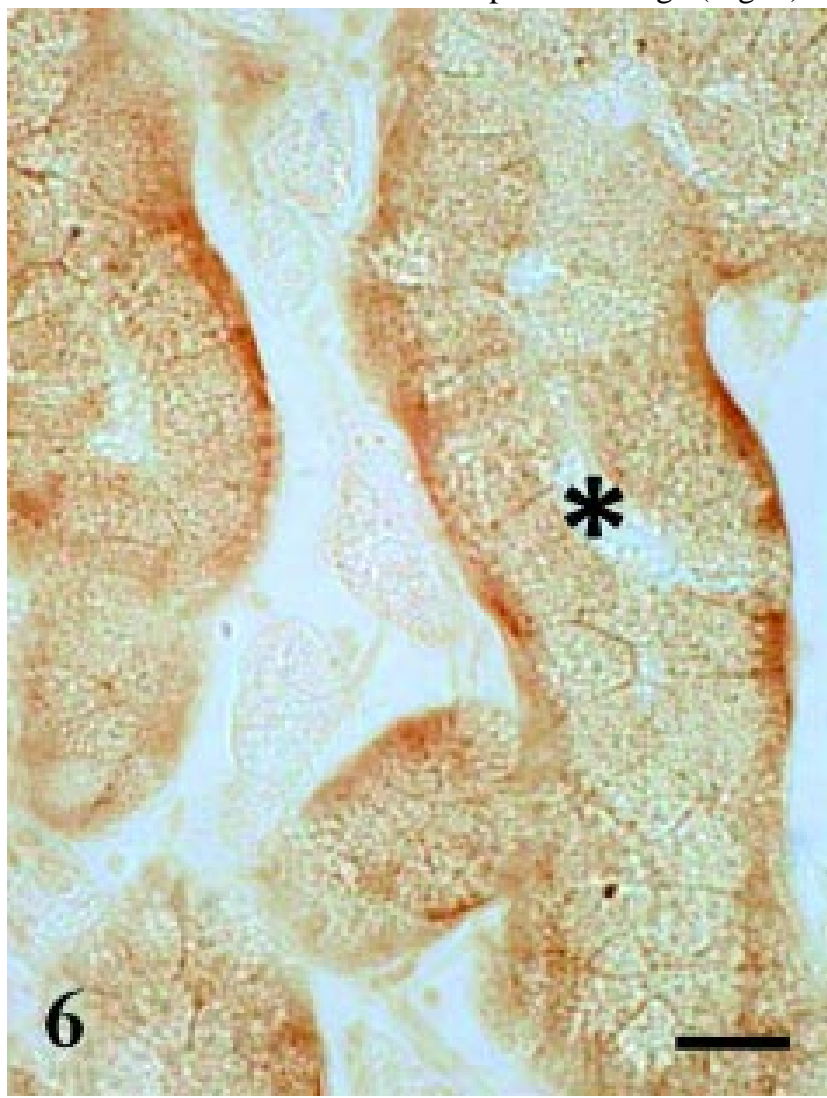

Fig. 6. Granular convoluted ducts (*) of submandibular gland on P8W. No distinct immunoreaction along the lateral plasmalemma of individual ductal cells although the diffuse immunoreaction is still discerned in the cytoplasm.

Sublingual gland. Whereas no immunoreactivity was detected in any portions of the sublingual gland from P1D till P3W, the immunoreactivity was seen in almost all demilune acinar cells on $\mathrm{P} 4 \mathrm{~W}$ and the reaction materials were diffusely localized in the cytoplasm, but not in the nucleus (Fig. 7). The immunoreactivity was also seen in ductal cells of excretory ducts with the apical plasmalemma more distinct. On P6W, the immunoreactivity decreased remarkably and no immunopositive cells were detected throughout the gland on P8W.

Fig. 8. Immunopositive reaction in neurons of parasympathetic salivary ganglion on $\mathrm{P} 4 \mathrm{~W}$ of mice. Arrow indicates immunonegative neuron. However, no nerve fibers/terminals immunopositive for CB1 were found to surround the glandular ducts and acini throughout the development. Bar represents $20 \mu \mathrm{m}$.

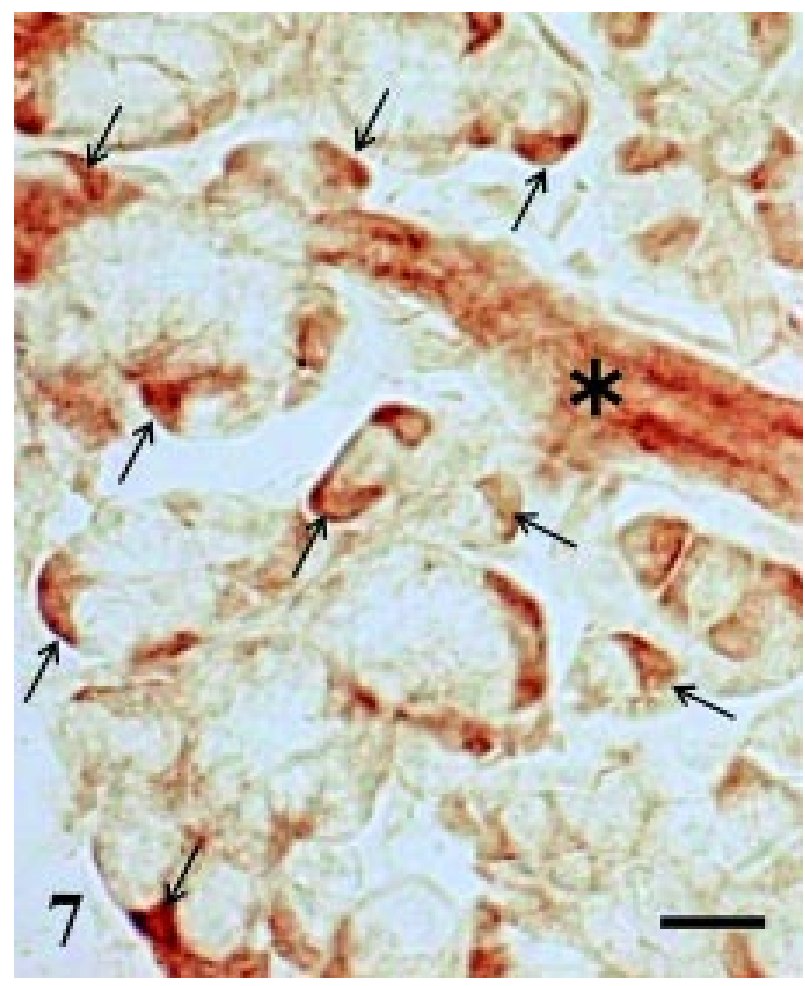

Fig. 7. Immunopositive reaction in demilune acinar cells (arrows) of sublingual gland on $\mathrm{P} 4 \mathrm{~W}$ of mice. Distinct immunoreaction deposits are seen in the apical plasmalemma of the intralobular ductal cells (*). Bar represents $20 \mu \mathrm{m}$.

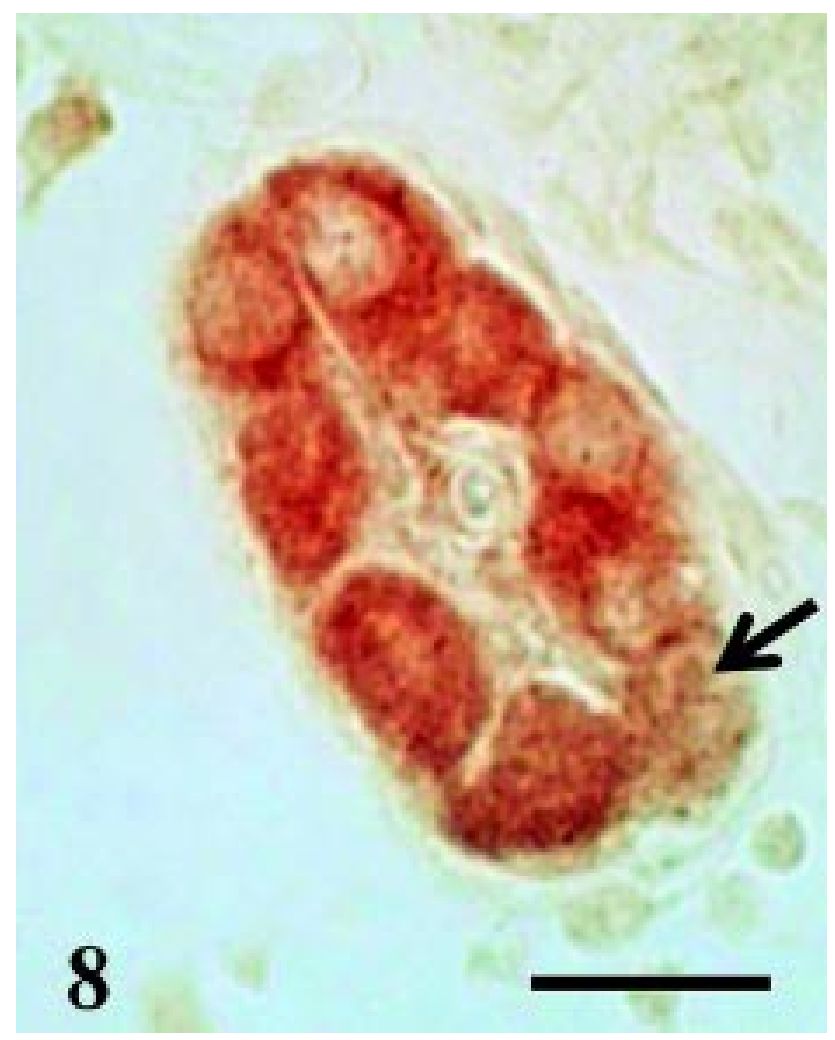


Parasympathetic salivary ganglia. In addition to the glandular cells, moderate CB1-immunoreactivity was also detected in the submandibular and sublingual ganglia throughout the postnatal development till P8W (Fig. 8). The immunoreactivity was diffused in the cytoplasm of most individual ganglion cells. However, some of the cells were immunonegative. In contrast, no nerve fibers and terminals immunopositive for CB1 were detected to surround the glandular ducts or acini throughout the postnatal development.

In control experiments, omission of the primary antibodies alone resulted in the abolition of all immunostaining (not shown).

\section{DISCUSSION}

In accord with the previous finding in the submandibular gland of adult rats (Prestifilippo et al.), the present study confirmed dominant CB1-immunoreactivity confined to the ductal cells of the proximal and distal intralobular ducts of the submandibular gland in young adult mice on $\mathrm{P} 4 \mathrm{~W} \sim \mathrm{P} 8 \mathrm{~W}$. Although the site to produce $\mathrm{eCB}$ in the gland remains to be elucidated, it is likely that CB1 in the ductal cells causes qualitative and quantitative modifications of the saliva secretion at adult stages. In addition, the well-known fact that human users of marijuana cause a reduction in the amount of saliva is explained in such a way that the effect of exogenous ligands for cannabinoid receptor is mediated through CB1 in the ductal, but not acinar, system.

With regard to the subcellular localization in the ductal cells, the difference between the intercalated portion and granular convoluted portion should be noted: the distinct immunoreactivity in the apical plasmalemma of the intercalated ductal cells versus the basal plasmalemma of the granular ductal cells on P4W. In view of the distinct localization on the apical plasmalemma in the sublingual gland ducts, it is likely that the apical plasmalemmal localization is the prototype for the CBinhibitory regulation in the ductal excretory function, and the basal plasmalemmal localization is special to the granular convoluted ductal portion which is dominantly involved in the secretion of granule contents. In addition, the transient enhanced appearance in the lateral plasmalemma of the granular ductal cells on P6W is also to be noted. It remains to be elucidated whether or not some enhanced inhibitory responses to eCB stimuli confined to this postnatal stage can occur in terms of the granule secretion in the ductal cells.

On the other hand, the present study disclosed for the first time the occurrence of CB1-immunoreactivity in the demilune acinar cells of the sublingual gland at young adult stages confined to P4W. Although the occurrence of CB-2immunoreactivity was already reported in the demilune acinar cells of the submandibular gland of adult rats (Prestifilippo $e t$ $a l$. ), it is unlikely that the present finding is due to a possible cross-reactivity of the present antibody with $\mathrm{CB} 2$, because the specificity was already confirmed by employing CB1 gene knockout mice (Uchigashima et al.), and further because no immunoreactivity was detected with the present antibody in corresponding acinar cells in adult mouse submandibular cells. It is possible to consider that CB1 exerts some modifications on the saliva secretion in the sublingual acinar system as well as the excretory system in a way different from the submandibular gland, although confined to the limited young adult stages, at least in mice.

The present study also disclosed the occurrence of CB1immunoreactivity in the salivary parasympathetic ganglion. Although the localization of CB1mRNA in the otic ganglion, which is another parasympathetic one, has been reported (Buckley et al., 1998), this is the first report demonstrating the occurrence of CB1-protein in the salivary parasympathetic ganglion. This finding suggests that $\mathrm{CB} 1$ is localized in the postganglionic neuronal terminals, in which the $\mathrm{CB} 1$ plays a regulatory role on the saliva secretion by inhibition of acetylcholine release, in addition to the role of CB1 in the ductal cells. However, no nerve fibers and terminals immunopositive for $\mathrm{CB} 1$ were discerned surrounding the glandular acini and ducts. There have been reports demonstrating clearly CB1immunopositive nerve fibers/terminals in the central nervous system by immunohistochemistry using the same antibody as employed in the present study (Uchigashima et al.). It is possible that CB1 in peripheral parasympathetic nerve fibers/ terminals is much lower than the immunohistochemical detection level unlike their neuronal somata, suggesting the main functional exertion at the soma. This possibility remains to be elucidated. With regard to the functional significance of CB1 in autonomic ganglia, the voltage-dependent modulation of natively expressed $\mathrm{N}$-type $\mathrm{Ca}+2(\mathrm{CaV} 2.2)$ channels has been shown following extracellular application of 2-AG in sympathetic neurons heterologously expressing $\mathrm{CB} 1$ receptor (Won et al., 2009). It is necessary to look for the origin of eCBs which could bind with the parasympathetic postganglionic $\mathrm{CB} 1$ in the salivary gland.

Finally, the occurrence of CB1-like immunoreactivity in forms of apical secretory granules in the submandibular acinar cells at newborn and P1W stages is briefly noted. The occurrence in forms of apical secretory granules is incompatible with this receptor nature belonging to the superfamily of G-protein-linked membrane receptors. It is crucial to examine first the authenticity of the immunoreactivity for CB1 for consideration of the functional significance of this peculiar localization of CB1-like immunoreactivity. 
ACKNOWLEDGEMENTS. This work was supported by Invitation Research Grant, Faculty of Medicine, Khon Kaen University (No. I57202) to WH. We sincerely thank Mr. D. Hipkaeo for his technical support.

HIPKAEO, W.; WATANABE, M. \& KONDO, H. Localización de los receptores de cannabinoides 1 (CB1) en glándulas salivales submandibulares y sublinguales de ratones durante el desarrollo postnatal. Int. J. Morphol., 33(2):695-700, 2015.

RESUMEN: En vista de que los usuarios humanos de la marihuana a menudo presentan síntomas de sequedad oral, en el presente estudio se intentó examinar la localización de CB1, que se identificó originalmente en el cerebro, en las glándulas salivales submandibulares y sublinguales durante el desarrollo postnatal en ratones machos. En la glándula submandibular, la inmunoreactividad CB1 fue positiva en la mayoría de las células acinares de apariencia granular en su citoplasma apical, mientras que fue negativa en los conductos en la etapa de recién nacidos. La inmunorreactividad disminuyó en las células acinares en P1W y no se detectó inmunoreactividad en las células acinares en P3W. La inmunoreactividad fue positiva en las células ductales en P3W y se mantuvo positiva hasta la etapa P8W. La inmunorreacción se observó en el plasmalema apical de las células ductales intercaladas, mientras que fue distinta en el plasmalema basal de las células ductales contorneadas granulares. La inmunotinción mejorada en el plasmalema lateral de las células ductales granulares fue distingible sólo en P6W. En la glándula sublingual, se detectó inmunoreactividad CB1 en las células acinares y se observaron células ductales solamente en P4W. Además, se demostró que la inmunoreactividad CB1 se produce en las neuronas ganglionares salivales, lo que sugiere la acción CB1 inhibitoria en la secreción de saliva a través de la transmisión parasimpática nerviosa.

PALABRAS CLAVE: Receptores de cannabinoides 1; Inmunohistoquímica; Glándula submandibular; Glándula sublingual; Ratón postnatal.

\section{REFERENCES}

Buckley, N. E.; Hansson, S.; Harta, G. \& Mezey, E. Expression of the CB1 and $\mathrm{CB} 2$ receptor messenger RNAs during embryonic development in the rat. Neuroscience, 82(4):1131-49, 1998.

Busch, L.; Sterin-Borda, L. \& Borda, E. Expression and biological effects of CB1 cannabinoid receptor in rat parotid gland. Biochem. Pharmacol., 68(9):1767-74, 2004.

Dall'Aglio, C.; Mercati, F.; Pascucci, L.; Boiti, C.; Pedini, V. \& Ceccarelli, P. Immunohistochemical localization of CB1 receptor in canine salivary glands. Vet. Res. Commun., 34 (Suppl. 1):S9-12, 2010.

Denny, P. C.; Chai, Y.; Pimprapaiporn, W. \& Denny, P. A. Three-dimensional reconstruction of adult female mouse submandibular gland secretory structures. Anat. Rec., 226(4):489-500, 1990.

Freund, T. F.; Katona, I. \& Piomelli, D. Role of endogenous cannabinoids in synaptic signaling. Physiol. Rev., 83(3):1017-66, 2003.
Kano, M.; Ohno-Shosaku, T.; Hashimotodani, Y.; Uchigashima, M. \& Watanabe, M. Endocannabinoid-mediated control of synaptic transmission. Physiol. Rev., 89(1):309-80, 2009.

Kopach, O.; Vats, J.; Netsyk, O.; Voitenko, N.; Irving, A. \& Fedirko, N. Cannabinoid receptors in submandibular acinar cells: functional coupling between saliva fluid and electrolytes secretion and $\mathrm{Ca} 2+$ signalling. J. Cell. Sci., 125 (Pt. 8):1884-95, 2011.

Matsuda, L. A. Molecular aspects of cannabinoid receptors. Crit. Rev. Neurobiol., 11(2-3):143-66, 1997.

Matsuda, L. A.; Lolait, S. J.; Brownstein, M. J.; Young, A. C. \& Bonner, T. I. Structure of a cannabinoid receptor and functional expression of the cloned cDNA. Nature, 346(6284):561-4, 1990.

Navarrete, M. \& Araque, A. Endocannabinoids potentiate synaptic transmission through stimulation of astrocytes. Neuron, 68(1):11326, 2010.

Osborne, K. D.; Lee, W.; Malarkey, E. B.; Irving, A. J. \& Parpura, V. Dynamic imaging of cannabinoid receptor 1 vesicular trafficking in cultured astrocytes. A. S. N. Neuro., 1(5):pii:AN20090040, 2009.

Pertwee, R. G. Cannabinoids and the gastrointestinal tract. Gut, 48(6):85967, 2001

Prestifilippo, J. P.; Fernández-Solari, J.; de la Cal, C.; Iribarne, M.; Suburo, A. M.; Rettori, V; McCann, S. M. \& Elverdin, J. C. Inhibition of salivary secretion by activation of cannabinoid receptors. Exp. Biol. Med. (Maywood), 231(8):1421-9, 2006.

Sanger, G. J. Endocannabinoids and the gastrointestinal tract: what are the key questions? Br. J. Pharmacol., 152(5):663-70, 2007.

Uchigashima, M.; Narushima, M.; Fukaya, M. Katona, I.; Kano, M. \& Watanabe, M. Subcellular arrangement of molecules for 2arachidonoyl-glycerol-mediated retrograde signaling and its physiological contribution to synaptic modulation in the striatum. $J$. Neurosci., 27(14):3663-76, 2007.

Won, Y. J.; Puhl, H. L. 3rd. \& Ikeda, S. R. Molecular reconstruction of mGluR5a-mediated endocannabinoid signaling cascade in single rat sympathetic neurons. J. Neurosci., 29(43):13603-12, 2009.

Wright, K. L.; Duncan, M. \& Sharkey, K. A. Cannabinoid CB2 receptors in the gastrointestinal tract: a regulatory system in states of inflammation. Br. J. Pharmacol., 153(2):263-70, 2008.

Zajicek, G.; Yagil, C. \& Michaeli, Y. The streaming submandibular gland. Anat. Rec., 213(2):150-8, 1985.

Correspondence to:

Wiphawi Hipkaeo

Department of Anatomy

Faculty of Medicine

Khon Kaen University

Muang, Khon Kaen 40002

THAILAND

Email: wiphawi@kku.ac.th hipkaeo1@hotmail.com

Received: 10-08-2014

Accepted: 04-03-2015 